\title{
The rise of Vulpia myuros (Poaceae) and the impact of cultivation-timing on plant community structure.
}

\author{
Michael J. Crawley \\ Imperial College, London, U.K.
}

\section{Corresponding author: m.crawley@imperial.ac.uk}

This pdf constitutes the Version of Record published on $16^{\text {th }}$ September 2021

\begin{abstract}
Vulpia myuros (L.) C.C. Gmel. has shown a dramatic increase in abundance as a weed of winter wheat since 2000 , especially under regimes of no-till husbandry. A long-term experiment on disturbance timing at Silwood Park suggests that this increase is probably not due solely to no-till cultivation or to the plant's well-known herbicide resistance, but rather to autumn cultivation coupled with warmer winter weather.
\end{abstract}

Keywords: phenology; timing of cultivation; seed bank; disturbance

\section{Introduction}

The study of phenology (the science of the timing of things) has experienced a renaissance since the search for evidence of the impacts of climate change has become so pressing (Fitchett et al, 2015). There are fundamental ecological questions involved in this. For instance, it is important to know how many of the differences between neighbouring plant communities are due to year effects (temporal heterogeneity, e.g. in the timing of soil disturbance) rather than to underlying spatial heterogeneity in soil structure, nutrient concentrations, water regime, herbivore impacts or microclimate. Year-to-year variation in the timing and intensity of inputs such as rainfall, changes in fitness-affecting weather variables such as the earliness of spring, and fluctuation in abiotic drivers such as frosts, fire, or soil disturbance all have the potential to alter species interactions, resulting in long-term consequences for botanical composition and succession (Crawley, 1997). Seedbank emergence dynamics are affected by ecological soil factors and buried weed seed germination and dormancy (Buhler et al., 1997) and by responses to climatic (Forcella et al., 1992), ecological (Benvenuti \& Macchia, 1997), and agronomic practice (Froud-Williams et al., 1984).

We know that species differ in their timing of germination (Buhler et al., 1997), and predict that species are likely to increase in abundance when the disturbance regime matches their preferred recruitment time (Crawley, 2004). Thus, spring germinators should increase under repeated spring cultivation, and autumn germinators should increase under autumn cultivation. Some species, however, might be capable of germination at any time. If germination were stimulated by disturbance at whatever time it occurred, then such species would be predicted to increase in abundance under any regular annual disturbance. If, however, 
germination were to occur independent of disturbance, then such species might decline in abundance if, on average, they did not reach fruiting size by the time of disturbance. It is likely, therefore, that there will be strong selection for species that germinate immediately after disturbance, and selection against species that germinate before disturbance but do not ripen seed before they are killed by cultivation. This was the pattern observed after 10 years of a long-term disturbance timing experiment at Silwood Park in Berkshire (Crawley, 2004): dominance, relative abundance and species composition were all significantly different on replicated plots cultivated in October, March or May each year (see Appendix A).

Since 2000, there has been a pronounced increase in the importance of Vulpia myuros as a weed of winter wheat, particularly on farms practicing no-till cultivation. This increase is variously attributed to the plant's well-documented herbicide resistance (Büchi et at., 2020) and/or to some factor associated with no-till cultivation (Akhter et al., 2020). The Pound Hill Experiment at Silwood Park has documented a similar increase in the abundance of $V$. myuros, and therefore provides an indirect opportunity to test the hypothesis that the increase in $V$. myuros is caused by no-till husbandry coupled with herbicide resistance.

\section{Methods}

Pound Hill Field at Silwood Park, Berks, is a long-term disturbance-timing experiment on acid, sandy soils of the Bagshot series (Crawley, 2004). Within the field, an area of $100 \mathrm{~m} \times 40 \mathrm{~m}$ was divided into 12 plots of $36 \mathrm{~m} \times 8 \mathrm{~m}$ in October 1992. This allowed replication of three timings of cultivation (October, March, or May each year) randomized independently in four blocks ( $A$ at the southern end to $D$ at the northern end). The plots were ploughed on their long axis (east to west) using a tractormounted two-furrow plough, and then the ground was rotovated to smooth out the furrows and create a fine seedbed. The plots were then left entirely alone for the plant community to develop, either by recruitment from the seed bank or by immigration of seeds from adjacent plant communities. Seeds ripened between April (for the earliest flowering species such as Myosotis discolor and Arabidopsis thaliana on October-cultivated plots) and August (for the latest flowering species such as Galinsoga parviflora and Solanum nigrum on May-cultivated plots).

The data presented in this paper were collected on 30 June 2021 by visual estimates of percentage cover for every species encountered on two zigzag walks over the long axis of each $36 \mathrm{~m} \times 8 \mathrm{~m}$ plot. By this date, the October-cultivated plots had been growing for 8 months, the March-cultivated plots for 3 months and the May-cultivated plots for just 1 month. There was negligible bare ground on the October- or March-cultivated plots by this date, but the May-cultivated plots still had c. $45 \%$ bare ground. One individual of a species is scored as 0.1 and two as 0.2 , so that species-richness data are inclusive.

The data reported in Crawley (2004) were from a one-off test of the impact of 10 years of contrasting cultivation times on the species-composition of the seed bank (1992-2002). The whole experiment (3 cultivation timings in each of 4 blocks) was split along its east-west axis and, at random, the eastern half was chosen to be cultivated in October 2002, and the western half in May 2003. The data were gathered in late July 2003 from all 24 sub-plots ( 2 current cultivation timings, 3 long-term cultivation treatments (October, March and May) and 4 blocks). The main 
findings are summarised in Appendix A \& B for comparison with the 2021 data published here.

The data in Appendix $\mathrm{C}$ show the botanical composition of May-cultivated plots at the end of their 2018 growing season, for comparison with the early-season results reported here from June 2021.

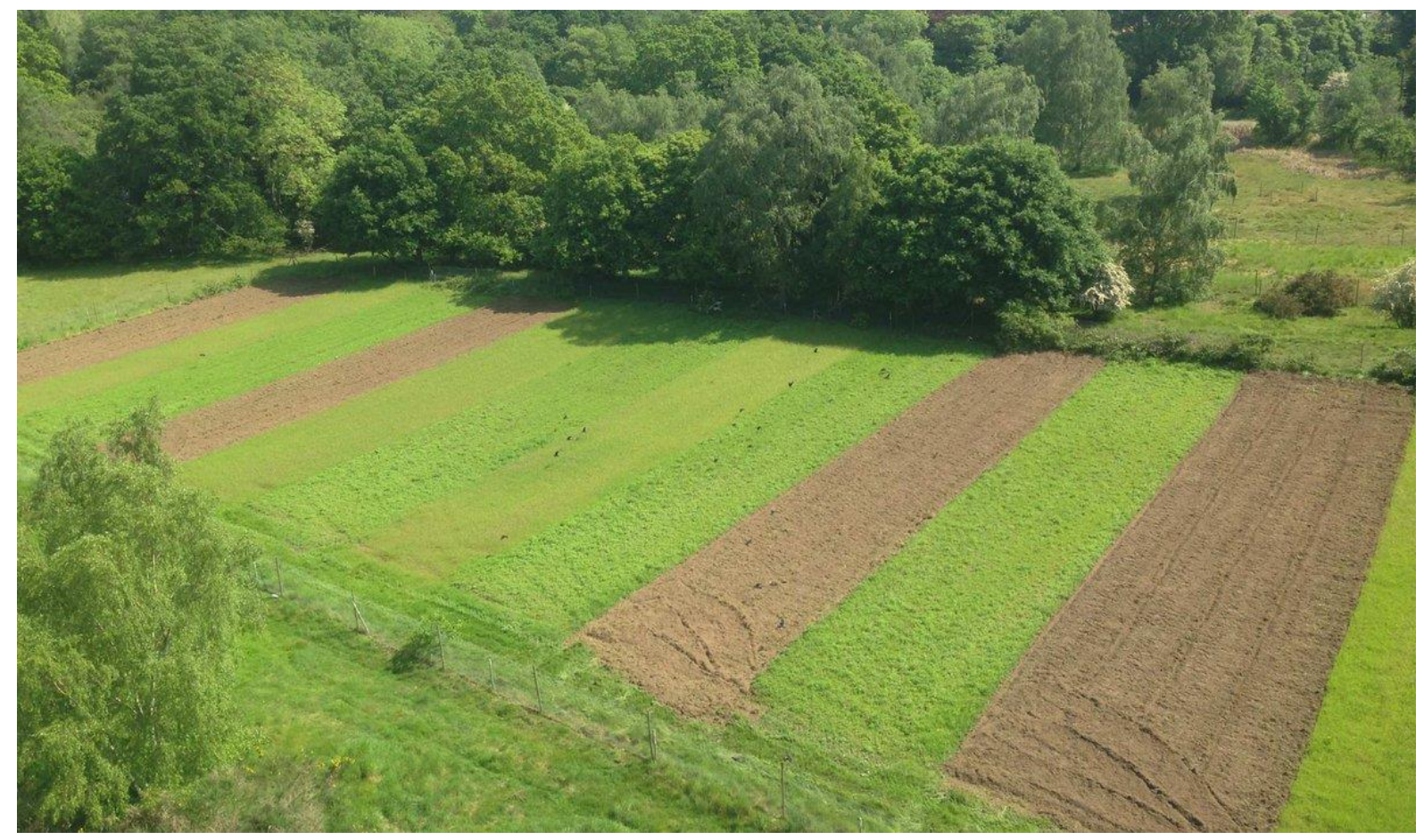

Figure 1. Pound Hill Field, Silwood Park, on the day of the May cultivation treatment

\section{Results}

Table 1 shows the percentage cover of vascular plant species ranked by mean cover on 30 June 2021 on plots cultivated in October each year in blocks A-D. The plots were dominated by rhizomatous perennial grasses (Holcus mollis and Agrostis gigantea), an annual grass (Vulpia myuros) and two herbs (Rumex acetosella and Arenaria leptoclados). Species restricted to the October cultivated plots on this date were Vulpia myuros, Arenaria leptoclados, Stellaria graminea+, Myosotis arvensis, Quercus robur seedlings ${ }^{+}$, Arrhenatherum elatius ${ }^{+}$, Veronica chamaedrys ${ }^{+}$, Hypericum perforatum ${ }^{+}$, Phleum bertolonii ${ }^{+}$, Epilobium montanum, Ervum tetraspermum, Heracleum sphondylium ${ }^{+}$, Cerastium fontanum ${ }^{+}$, Ranunculus repens ${ }^{+}$, Rumex acetosa ${ }^{+}$, Vicia sativa subsp. nigra ${ }^{+}$, Prunus sp. seedling, Veronica arvensis and Vicia cracca, with a preponderance of species probably recruited from the uncultivated surrounding acid grassland (shown by ${ }^{+}$).

There was no record of Vulpia myuros at Pound Hill up to 2003 (Crawley, 2004) and the first record was obtained in May 2004, just prior to cultivation of the May-cultivated plots $A, B \& D$. These plants had probably germinated in autumn 2003. By 2016, however, V. myuros was at $65 \%$ cover on Block A and $5 \%$ on Block $\mathrm{D}$ (average $28.75 \%$ ) on the October cultivated plots, but absent from March and May. A similar picture was obtained in June 2021 from other Silwood fields cultivated in October, but not treated with any herbicide since 2002 or earlier: Ashurst Four 
Acre Field (SU940683, 32\% cover of V. myuros), Met Tower Field (SU937693, 40\%), Lysimeters (SU940685, 45\%) and Silwood Bottom (SU944688, a gradient from 68\% to $5 \%$ cover; note that the May-cultivated southern section of Silwood Bottom (SU944687) had no $V$. myuros on this date). It is clear that $V$. myuros has undergone a substantial increase in abundance on autumn-cultivated ground throughout Silwood Park since 2005 without any herbicide application.

Table 2 shows the percentage cover of vascular plant species ranked by mean cover on 30 June 2021 on plots cultivated in March each year in blocks A-D. All four replicates were dominated by virtual monocultures of Artemisia vulgaris ( $80 \%$ mean cover). Species restricted to the March cultivated plots on this date were annual herbs (Medicago Iupulina, Polygonum aviculare, Sisymbrium officinale, Matricaria chamomilla) and perennial grasses (Elymus repens, Dactylis glomerata, Festuca rubra).

Table 3 shows the percentage cover of vascular plant species ranked by mean cover on 30 June 2021 on plots cultivated in May each year in blocks A-D. There was still $c .40 \%$ of bare soil but the wet May and June weather had allowed rapid growth of Agrostis gigantea, Galinsoga parviflora, Spergula arvensis, Rumex acetosella, Fallopia convolvulus, Holcus mollis, Chenopodium album, Erodium cicutarium and Lycopsis arvensis. Species restricted to the May cultivated plots on this date were Galinsoga parviflora, Lamium amplexicaule, Vulpia bromoides, Anagallis arvensis, Hypochaeris radicata, Cerastium glomeratum, Convolvulus arvensis, Geranium molle, Veronica persica and Sonchus oleraceus.

Total species richness across the four replicates was not markedly different with cultivation timing, but ranked as follows: October (36 species) > May (33) > March (31).

\section{Discussion}

Three guilds of species were apparent in the Pound Hill Experiment: autumn germinators, spring germinators (seeds with a chilling requirement to break dormancy), and indifferent species (species germinating after disturbance, irrespective of timing). Some species were driven close to local extinction by annual soil disturbance at the 'wrong' time of year; presumably their seed banks were small or rapidly depleted, and recruitment to their populations may have been more reliant on the annual seed rain.

Cultivation in a given month represents extremely strong selection in favour of annual plants that can germinate after that month and set seed before the next cultivation, and of perennial plants that can withstand fragmentation and burial in that particular month (e.g. the dominance of March-cultivated plots by Artemisia vulgaris and of October-cultivated plots by Holcus mollis and Agrostis gigantea). The ability to survive over winter or through summer drought clearly differs in relative importance for species germinating in October, March or May. Comparison of Tables 1, 2 \& 3 highlights clear differences in species composition, with groups of species confined entirely to a single cultivation-timing treatment (there were 19 species restricted to October-cultivated plots, 7 to March-cultivated plots, and 10 to May-cultivated plots). 
Table 1. Percentage cover on 30 June 2021 of plots cultivated in October each year in 4 blocks (A-D) ranked by mean cover. Species restricted to this cultivation timing are shown with $* * *$

Taxon

Holcus mollis

Rumex acetosella

Vulpia myuros ***

Agrostis gigantea

Arenaria leptoclados ***

Aphanes australis

Bromus hordeaceus

Anisantha sterilis

Achillea millefolium

Plantago lanceolata

Artemisia vulgaris

Ervilia hirsuta

Apera spica-venti

Papaver dubium

Stellaria graminea ***

Crepis capillaris

Myosotis arvensis ***

Quercus robur seedlings ***

Viola arvensis

Arrhenatherum elatius ***

Cirsium arvense

Veronica chamaedrys ***

Hypericum perforatum ***

Phleum bertolonii ***

Epilobium montanum ***

Ervum tetraspermum ***

Heracleum sphondylium ***

Cerastium fontanum ***

Spergula arvensis

Ranunculus repens ***

Rumex acetosa ***

Vicia sativa subsp. nigra ***

Prunus sp. seedling ***

Lycopsis arvensis

Veronica arvensis ***

Vicia cracca ***

\begin{tabular}{|c|c|c|c|c|c|}
\hline A & B & C & D & mean & frequency \\
\hline 70 & 70 & 75 & 80 & 73.75 & 100 \\
\hline 15 & 30 & 15 & 20 & 20 & 100 \\
\hline 25 & 20 & 5 & 10 & 15 & 100 \\
\hline 15 & 20 & 10 & 15 & 15 & 100 \\
\hline 0 & 0 & 30 & 25 & 13.75 & 50 \\
\hline 8 & 15 & 10 & 5 & 9.5 & 100 \\
\hline 5 & 8 & 8 & 5 & 6.5 & 100 \\
\hline 8 & 10 & 5 & 2 & 6.25 & 100 \\
\hline 5 & 1 & 2 & 10 & 4.5 & 100 \\
\hline 0 & 3 & 3 & 5 & 2.75 & 75 \\
\hline 5 & 5 & 0.1 & 0 & 2.525 & 75 \\
\hline 2 & 2 & 2 & 2 & 2 & 100 \\
\hline 0 & 0 & 8 & 0 & 2 & 25 \\
\hline 2 & 1 & 1 & 2 & 1.5 & 100 \\
\hline 5 & 0 & 0 & 0 & 1.25 & 25 \\
\hline 0.1 & 1 & 2 & 1 & 1.025 & 100 \\
\hline 1 & 1 & 1 & 1 & 1 & 100 \\
\hline 1 & 1 & 1 & 1 & 1 & 100 \\
\hline 1 & 0.1 & 2 & 0 & 0.775 & 75 \\
\hline 2 & 0 & 0 & 0.1 & 0.525 & 50 \\
\hline 2 & 0 & 0 & 0 & 0.5 & 25 \\
\hline 2 & 0 & 0 & 0 & 0.5 & 25 \\
\hline 1 & 0.1 & 0.1 & 0.1 & 0.325 & 100 \\
\hline 1 & 0 & 0 & 0 & 0.25 & 25 \\
\hline 1 & 0 & 0 & 0 & 0.25 & 25 \\
\hline 1 & 0 & 0 & 0 & 0.25 & 25 \\
\hline 1 & 0 & 0 & 0 & 0.25 & 25 \\
\hline 1 & 0 & 0 & 0 & 0.25 & 25 \\
\hline 0 & 0.2 & 0 & 0 & 0.05 & 25 \\
\hline 0.1 & 0 & 0 & 0 & 0.025 & 25 \\
\hline 0.1 & 0 & 0 & 0 & 0.025 & 25 \\
\hline 0.1 & 0 & 0 & 0 & 0.025 & 25 \\
\hline 0 & 0.1 & 0 & 0 & 0.025 & 25 \\
\hline 0 & 0.1 & 0 & 0 & 0.025 & 25 \\
\hline 0 & 0 & 0.1 & 0 & 0.025 & 25 \\
\hline 0 & 0 & 0 & 0.1 & 0.025 & 25 \\
\hline
\end{tabular}


Table 2. Percentage cover on 30 June 2021 of plots cultivated in March each year in 4 blocks (A-D) ranked by mean cover. Species restricted to this cultivation

timing are shown with $* * *$

Taxon

Artemisia vulgaris

Agrostis gigantea

Medicago lupulina ***

Raphanus raphanistrum

Holcus mollis

Chenopodium album

Bromus hordeaceus

Achillea millefolium

Fallopia convolvulus

Lycopsis arvensis

Plantago lanceolata

Papaver dubium

Rumex crispus

Arabidopsis thaliana

Viola arvensis

Ervilia hirsuta

Aphanes australis

Capsella bursa-pastoris

Polygonum aviculare ***

Spergula arvensis

Sisymbrium officinale ***

Anisantha sterilis

Sonchus asper

Matricaria chamomilla ****

Apera spica-venti

Erodium cicutarium

Crepis capillaris

Elymus repens ***

Erigeron canadensis

Dactylis glomerata ***

Festuca rubra ***
A B C

85

20

15

15

10

3

8

8

1

2

2

1

2

5

3

1

3

1

1

2

1

1

1

1

0

0

0

0.1

0.1

0

0

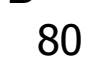

25

15

8

12

2

10

5

3

3

5

1

1

1

0.1

2

2

1

1

1

1

0.1

0.1

0

0

0

0

0

0

0

0.1

0.1
C

75

30

15

5

5

2

2

8

8

8

8

5

2

2

5

1

1

1

3

0

1

1

0

0

0

0

0

0

0

1

1

1

0

0

0

0

0
D mean frequency

$\begin{array}{lll}80 & 80 & 100\end{array}$

$\begin{array}{lll}40 & 28.75 & 100\end{array}$

$\begin{array}{lll}25 & 17.5 & 100\end{array}$

$\begin{array}{lll}10 & 9.5 & 100\end{array}$

$8 \quad 8 \quad 100$

$\begin{array}{lll}25 & 8 & 100\end{array}$

$\begin{array}{lll}5 & 7.75 & 100\end{array}$

$\begin{array}{lll}8 & 7.25 & 100\end{array}$

$\begin{array}{lll}5 & 4.25 & 100\end{array}$

$5 \quad 3.75 \quad 100$

$\begin{array}{lll}2 & 2.75 & 100\end{array}$

$\begin{array}{lll}5 & 2.25 & 100\end{array}$

$\begin{array}{lll}1 & 2.25 & 100\end{array}$

$\begin{array}{lll}1 & 1.775 & 100\end{array}$

$\begin{array}{lll}0.1 & 1.525 & 100\end{array}$

$\begin{array}{lll}0.1 & 1.525 & 100\end{array}$

$\begin{array}{lll}0 & 1 & 50\end{array}$

$\begin{array}{lll}1 & 1 & 100\end{array}$

$\begin{array}{lll}2 & 1 & 75\end{array}$

$\begin{array}{lll}0 & 0.75 & 50\end{array}$

$\begin{array}{lll}1 & 0.525 & 75\end{array}$

$\begin{array}{lll}0 & 0.275 & 50\end{array}$

$\begin{array}{lll}0 & 0.25 & 25\end{array}$

$\begin{array}{lll}0 & 0.25 & 25\end{array}$

$\begin{array}{lll}0 & 0.25 & 25\end{array}$

$\begin{array}{lll}0 & 0.25 & 25\end{array}$

$\begin{array}{lll}1 & 0.25 & 25\end{array}$

$\begin{array}{lll}0 & 0.025 & 25\end{array}$

$\begin{array}{lll}0 & 0.025 & 25\end{array}$

$\begin{array}{lll}0 & 0.025 & 25\end{array}$

$\begin{array}{lll}0 & 0.025 & 25\end{array}$ 
Table 3. Percentage cover on 30 June 2021 of plots cultivated in May each year in 4 blocks (A-D) ranked by mean cover. Species restricted to this cultivation timing are shown with $* * *$

Taxon

Agrostis gigantea

Galinsoga parviflora ***

Spergula arvensis

Rumex acetosella

Fallopia convolvulus

Holcus mollis

Chenopodium album

Erodium cicutarium

Lycopsis arvensis

Lamium amplexicaule ***

Raphanus raphanistrum

Erigeron canadensis

Artemisia vulgaris

Capsella bursa-pastoris

Achillea millefolium

Rumex crispus

Sonchus asper

Crepis capillaris

Vulpia bromoides ***

Lysimachia arvensis ***

Viola arvensis

Bromus hordeaceus

Crepis capillaris

Hypochaeris radicata ***

Cirsium arvense

Cerastium glomeratum ***

Convolvulus arvensis ***

Papaver dubium

Geranium molle ***

Veronica persica ***

Arabidopsis thaliana

Apera spica-venti

Sonchus oleraceus ***
A

25

5

15

20

20

15

10

8

8

8

10

2

8

1

5

8

1

1

0

0

0

0.1

1

1

1

1

0

0.1

0

0.1

0

0

0

40
B

45

2

10

15

10

5

8

5

5

5
8

8

5

5

5

5
1
0

0

0

2

0.1

3

1

0.1

0

1

0.1

0

0

0

0.1

0.1

0

0

0

0

C

40

15

15

5

15

2

8

8

10

2

5

0.1

1

2

3

3

1

2

0

2

0.1

1

0.1

0

0

1

0.2

0.1

0

0.1

0.1

0.1

45

45
D mean frequency

$15 \quad 31.25$

$45 \quad 16.75$

$15 \quad 13.75$

$10 \quad 12.5$

12

15

9.25

7.75

7.75

7

6.5

5.5

3.775

3.5

3.5

3.25

3

$0.2 \quad 1.05$

0.775

0.75

0.75

0.55

0.525

0.5

$0.1 \quad 0.325$

0.25

0.25

0.25

0.1

0.05

$0.1 \quad 0.05$

$\begin{array}{ll}0 & 0.025\end{array}$

$\begin{array}{ll}0 & 0.025\end{array}$

$\begin{array}{ll}0 & 0.025\end{array}$

20

Cultivation is highly likely to kill seedlings: this is presumably why seedlings of Quercus robur were found on all October cultivated plots, but not on any of those cultivated in March or May. Seedlings of frost-sensitive species may be killed by frosts on October- or March-cultivated plots but never (see Crawley, 2005, p. 31) on May-cultivated plots. Climatic conditions experienced by newly germinated seedlings are markedly different in October (warm and moist), March (cold and moist) and 
May (warm and dry), and this has consequences for interspecific competition during the rapid growth phase on each timing treatment. Year effects driven by seasonal weather differences are exemplified by a comparison of May-cultivated plots in 2021 after a wet growing period following a very cold dry spring (Table 3) and 2018 (Appendix C) after a long, hot, dry summer. The dominant in 2021 was Agrostis gigantea, but this was a mere trace in 2018. Galinsoga parviflora had more than 3 times the cover in 2021 as in 2018 (16\% vs. 5\%). The species that performed relatively well in the dry growing season of 2018 were Erodium cicutarium (20\%) and Spergula arvensis (15\%).

The marked increase in the distribution and abundance of Vulpia myuros in Silwood Park matches the recent rises that have been documented in no-till arable cultivation of winter wheat (Akhter et al., 2020), but the causes of the increase in Silwood Park are clearly not the same as those hypothesised in the weed science literature: viz. the use of no-till sowing technology coupled with the welldocumented herbicide resistance of the grass (Büchi et al., 2020). Cultivation in Silwood Park involved traditional inversion ploughing followed by rotovation, and no herbicides have been applied at Pound Hill since 2002 (Crawley, 2004). The timing of cultivation was crucial: $V$. myuros increased on plots cultivated in October, but not on those cultivated in March or April. It may well be that the increase documented from arable agriculture is driven by a more widespread cause such as increasing winter temperatures (Chapman et al., 2020) interacting with autumn cultivation. This analysis of the rise of $V$. myuros is another example of the way that long-term field experiments can be used to address questions that were never envisaged at the time the experiment was set up.

\section{References}

Akhter, M.J., Jensen, P.K., Mathiassen, S.K., Melander, B. \& Kudsk, P. 2020. Biology and management of Vulpia myuros - an emerging weed problem in no-till cropping systems in Europe. Plants 9, 715.

Benvenuti S. \& Macchiab, M. 1997. Light, phytochrome and germination of Datura stramonium L. seeds. Environmental and Experimental Botany 38: 61- 71.

Büchi, L., Cordeau, S., Hull, R. \& Rodenburg, J. 2020. Vulpia myuros, an increasing threat for agriculture. Weed Research 61: 13-24.

Buhler D.D., Hartzler, R.G. \& Forcella, F. 1997 Implications of weed seedbank dynamics to weed management. Weed Science 45: 329- 336.

Chapman, S.C., Murphy, E.J., Stainforth, D.A. \& Watkins, N.W. 2020. Trends in winter warm spells in the Central England temperature record. Journal of Applied Meteorology and Climatology 59: 1069-1076

Crawley, M.J. 1997. Life history and environment. In: Crawley, M.J. (ed.) Plant Ecology, $2^{\text {nd }}$ ed., pp. 73-131. Oxford: Blackwell Science.

Crawley, M.J. 2004. Timing of disturbance and coexistence in a species-rich ruderal plant community. Ecology 85: 3277-3288

Crawley, M.J. 2005. The Flora of Berkshire. Harpenden: Brambleby Books.

Fitchett, J.M., Grab, S.W. \& Thompson, D.I. 2015. Plant phenology and climate change: progress in methodological approaches and application. Progress in Physical Geography: Earth and Environment 39: 460-482 
Forcella F., Wilson, R.G., Renner, K.A., Dekker, J.H. \& Harvey, R.G. 1992. Weed seedbanks of the U.S. Corn Belt: magnitude, variation, emergence and application. Weed Science 40: 636- 644.

Froud-Williams, R.J., Chancellor, R.J., Drennan, D.S.H. 1984. The effects of seed burial and soil disturbance on emergence and survival of arable weeds in relation to minimal cultivation. Journal of Applied Ecology 1984. 21: 629- 641.

Copyright retained by author(s). Published by BSBI under the terms of the Creative Commons Attribution 4.0 International Public License.

ISSN: $2632-4970$

https://doi.org/10.33928/bib.2021.03.362 


\section{Appendix A.}

At Pound Hill in 2002-3, half of each plot had been cultivated in autumn 2002 and the other half in spring 2003. In late July 2003, Crawley (2004) found three categories of species: some were more abundant following autumn cultivation, some following spring cultivation, and others were indifferent to the timing of disturbance in 2002-3. As expected, autumn germinators typically declined under spring cultivation, and spring germinators typically declined under autumn cultivation. Some species had been driven to local extinction within 10 years by repeated cultivation at the wrong time of year (e.g., Lamium amplexicaule on March-cultivated plots and Erodium cicutarium on October-cultivated plots). Note the absence of Vulpia myuros from all plots.

a) More after autumn cultivation in 2002

Aphanes australis, Arabidopsis thaliana, Cerastium glomeratum, Myosotis discolor, Papaver dubium, Veronica arvensis, Veronica serpyllifolia, Sagina filicaulis, Arenaria leptoclados, Cerastium fontanum, Tripleurospermum inodorum, Galium aparine b) More after spring cultivation in 2003 Bromus hordeaceus, Chenopodium album, Galinsoga parviflora, Spergula arvensis, Solanum nigrum Artemisia vulgaris, Capsella bursa-pastoris, Senecio sylvaticus c) Indifferent to timing in 2002-3

Anisantha sterilis, Holcus mollis, Lycopsis arvensis, Lepidium didymum, Polygonum aviculare, Anagallis arvensis, Sonchus asper, Agrostis gigantea, Medicago lupulina, Veronica persica, Viola arvensis, Poa annua

\section{Appendix B}

Seed bank legacy effects of long-term disturbance timing (October, March, or May). Species peaked in cover in July 2003 (a) on both autumn- and spring cultivated plots; (b) on autumn-cultivated plots; and (c) on spring-cultivated plants. Note the absence of Vulpia myuros from all plots.

a) Following both autumn or spring cultivation in 2002-3

long-term October-cultivated plots

Anisantha sterilis, Arabidopsis thaliana, Arenaria leptoclados, Holcus mollis, Myosotis arvensis, Papaver dubium, Tripleurospermum inodorum, Ervilia hirsuta

long-term March-cultivated plots

Chenopodium album, Lamium amplexicaule, Veronica persica

long-term May-cultivated plots

Agrostis gigantea, Capsella bursa-pastoris, Erodium cicutarium, Galinsoga parviflora, Geranium molle, Poa annua

b) Only following autumn cultivation in 2002-3

long-term October-cultivated plots

Cerastium glomeratum, Galium aparine, Medicago lupulina, Polygonum aviculare,

Sagina filicaulis, Vulpia bromoides

long-term March-cultivated plots

Sonchus asper

long-term May-cultivated plots

Aphanes australis, Myosotis discolor, Taraxacum officinale agg. 
c) Only following spring cultivation in 2003

long-term October-cultivated plots

Bromus hordeaceus, Cerastium fontanum, Veronica arvensis

long-term March-cultivated plots

Lysimachia arvensis, Polygonum aviculare, Sisymbrium officinale, Viola arvensis long-term May-cultivated plots

Artemisia vulgaris, Persicaria maculosa, Spergula arvensis

Of the 37 species showing significant effects of disturbance timing on frequency, 17 peaked on October-cultivated plots, eight on March-cultivated plots, and 12 on Maycultivated plots.

\section{Appendix C}

Percentage cover of plots cultivated in May each year in 4 blocks (A-D) as measured at the end of their 5-month growing season in September 2018, ranked by mean cover. There was substantial bare ground following a long hot summer, but no sign of Vulpia myuros which by 2018 was locally abundant on the October-cultivated plots.

Species

bare ground

Erodium cicutarium

Spergula arvensis

Chenopodium album

Fallopia convolvulus

Lycopsis arvensis

Galinsoga parviflora

Artemisia vulgaris

Rumex crispus

Achillea millefolium

Rumex acetosella

Raphanus raphanistrum

Lysimachia arvensis

Cirsium arvense

Sonchus asper

Crepis capillaris

Capsella bursa-pastoris

Anisantha sterilis

Erigeron canadensis

Elymus repens

Agrostis gigantea

Veronica persica

Tripleurospermum

inodorum

Geranium molle

Sonchus oleraceus
Block Block Block Block

A B C D mean frequency

$\begin{array}{llllll}50 & 55 & 45 & 50 & 50 & 100\end{array}$

$\begin{array}{llllll}20 & 25 & 10 & 25 & 20 & 100\end{array}$

$\begin{array}{llllll}15 & 10 & 25 & 10 & 15 & 100\end{array}$

$\begin{array}{rrrrrr}8 & 10 & 8 & 15 & 10.25 & 100\end{array}$

$\begin{array}{llllll}20 & 10 & 10 & 1 & 10.25 & 100\end{array}$

$\begin{array}{llllll}4 & 4 & 10 & 3 & 5.25 & 100\end{array}$

$\begin{array}{llllll}5 & 5 & 8 & 3 & 5.25 & 100\end{array}$

$\begin{array}{llllll}5 & 4 & 0.1 & 0 & 2.275 & 75\end{array}$

$\begin{array}{llllll}5 & 2 & 2 & 0 & 2.25 & 75\end{array}$

$\begin{array}{llllll}3 & 1 & 2 & 1 & 1.75 & 100\end{array}$

$\begin{array}{llllll}5 & 1 & 1 & 0 & 1.75 & 75\end{array}$

$\begin{array}{rrrrrr}1 & 0 & 2 & 1 & 1 & 75\end{array}$

$\begin{array}{llllll}1 & 1 & 0.1 & 0.1 & 0.55 & 100\end{array}$

$\begin{array}{rrrrrr}2 & 0 & 0.1 & 0 & 0.525 & 50\end{array}$

$\begin{array}{llllll}1 & 0.1 & 0.2 & 0.1 & 0.35 & 100\end{array}$

$\begin{array}{llllll}1 & 0 & 0.1 & 0.2 & 0.325 & 75\end{array}$

$\begin{array}{rrrrrr}0.1 & 0.1 & 0.1 & 0.1 & 0.1 & 100\end{array}$

$\begin{array}{llllll}0 & 0 & 0.1 & 0.2 & 0.075 & 50\end{array}$

$\begin{array}{llllll}0.1 & 0 & 0 & 0.2 & 0.075 & 50\end{array}$

$\begin{array}{llllll}0.1 & 0.1 & 0 & 0 & 0.05 & 50\end{array}$

$\begin{array}{llllll}0 & 0 & 0.1 & 0.1 & 0.05 & 50\end{array}$

$\begin{array}{llllll}0 & 0 & 0 & 0.1 & 0.025 & 25\end{array}$

$\begin{array}{llllll}0 & 0 & 0.1 & 0 & 0.025 & 25\end{array}$

$\begin{array}{llllll}0 & 0 & 0.1 & 0 & 0.025 & 25\end{array}$

$\begin{array}{llllll}0 & 0 & 0.1 & 0 & 0.025 & 25\end{array}$ 